\title{
Review of the scientific evolution of gene therapy for the treatment of homozygous familial hypercholesterolaemia: past, present and future perspectives
}

\author{
Ricardo Rodriguez-Calvo (1) , Luis Masana
}

Vascular Medicine and Metabolism Unit, Research Unit on Lipids and Atherosclerosis, 'Sant Joan' University Hospital, Universitat Rovira i Virgili, Institut de Investigació Sanitaria Pere Virgili (IISPV), Spanish Biomedical Research Centre in Diabetes and Associated Metabolic Disorders (CIBERDEM), Reus, Spain

\section{Correspondence to}

Dr Ricardo Rodriguez-Calvo and Professor Luis Masana, Vascular Medicine and Metabolism Unit, Research Unit on Lipids and Atherosclerosis, 'Sant Joan' University Hospital, Universitat Rovira i Virgili, Institut de Investigació Sanitaria Pere Virgili (IISPV), Spanish Biomedical Research Centre in Diabetes and Associated Metabolic Disorders (CIBERDEM), Reus 43201,

Spain;

ricardo.rodriguez@ciberdem.

org,

luis.masana@urv.cat

Received 29 August 2018 Revised 12 February 2019 Accepted 16 February 2019 Published Online First 15 March 2019

\section{Check for updates}

(c) Author(s) (or their employer(s)) 2019. No commercial re-use. See rights and permissions. Published by BMJ.

To cite: Rodriguez-Calvo $R$, Masana L. J Med Genet 2019:56:711-717.

\section{ABSTRACT}

Familial hypercholesterolaemia (FH) is a devastating genetic disease that leads to extremely high cholesterol levels and severe cardiovascular disease, mainly caused by mutations in any of the main genes involved in lowdensity lipoprotein cholesterol (LDL-C) uptake. Among these genes, mutations in the $L D L$ receptor $(L D L R)$ are responsible for $80 \%-90 \%$ of the $\mathrm{FH}$ cases. The severe homozygous variety (HoFH) is not successfully treated with standard cholesterol-lowering therapies, and more aggressive strategies must be considered to mitigate the effects of this disease, such as weekly/biweekly LDL apheresis. However, development of new therapeutic approaches is needed to cure HoFH. Because HoFH is mainly due to mutations in the $L D L R$, this disease has been proposed as an ideal candidate for gene therapy. Several preclinical studies have proposed that the transference of functional copies of the $L D L R$ gene reduces circulating LDL-C levels in several models of $\mathrm{HoFH}$, which has led to the first clinical trials in humans. Additionally, the recent development of clustered regularly interspaced short palindromic repeat/CRISPRassociated 9 technology for genome editing has opened the door to therapies aimed at directly correcting the specific mutation in the endogenous $L D L R$ gene. In this article, we review the genetic basis of the FH disease, paying special attention to the severe $\mathrm{HoFH}$ as well as the challenges in its diagnosis and clinical management. Additionally, we discuss the current therapies for this disease and the new emerging advances in gene therapy to target a definitive cure for this disease.

\section{INTRODUCTION}

Familial hypercholesterolaemia $(\mathrm{FH})$ is usually a monogenic autosomal-dominant disease characterised by abnormally elevated serum levels of low-density lipoprotein cholesterol (LDL-C) and an extremely high risk of atherosclerosis and cardiovascular disease $(\mathrm{CVD})^{1}$ figure 1 . Whereas the heterozygous variety (HeFH) shows two to four times higher LDL-C levels, ${ }^{2}$ patients with the severe homozygous $\mathrm{FH}(\mathrm{HoFH})$ form can present plasma levels of LDL-C $>13 \mathrm{mmol} / \mathrm{L}^{3}$ Thus, patients with HoFH are at increased risk of developing severe CVD during the first decade of life, ${ }^{1}$ including aortic valve stenosis and coronary heart disease, requiring invasive therapies, ultimately leading to heart transplant. Additionally, they show both subcutaneous and tendinose cholesterol deposits (xanthomas) and corneal arcus before 10 years of age. These patients develop symptomatic atherosclerosis before 20 years of age and could die before they reach 30 years of age. ${ }^{4}$ The historical frequencies of $\mathrm{HeFH}$ and $\mathrm{HoFH}$ were estimated to be 1:500 and 1:1 000000 , respectively. ${ }^{4}$ However, given the founder effect of the genetic population, high frequencies have been described in specific populations. ${ }^{5}$ Thus, recent studies estimate that $\mathrm{HeFH}$ affects 1 in 200 people, ${ }^{2}$ and the prevalence of HoFH is approximately 1 in 160000-300000 people, including both true homozygous and composed heterozygous (both referred to as homozygous). ${ }^{367}$

Elevated levels of serum LDL-C are the result of the inability of $\mathrm{FH}$ patients to clear circulating cholesterol caused by mutations in any of the main genes involved in LDL uptake, including the LDL receptor (LDLR; OMIM \#606945), ${ }^{4}$ apolipoprotein B (APOB; OMIM \#107730), ${ }^{8}$ proprotein convertase subtilisin/kexin type 9 (PCSK9; OMIM \#607786) $)^{910}$ and low-density lipoprotein receptor adaptor protein 1 (LDLRAP1; OMIM \#695747). ${ }^{11}$ Among these genes, mutations in the LDLR are responsible for $80 \%-90 \%$ of the cases, ${ }^{12} 13$ encompassing $>2000$ mutations ${ }^{12}$ with a range of dysfunction of pathogenic variants between $<2 \%$ and $50 \%$ activity. Accordingly, it is possible to classify the LDLR into two categories: (1) receptor-negative or null-receptor mutations, with $<2 \%$ of activity and (2) receptor-defective, with $\geq 2 \%$ of residual activity. ${ }^{14}$ The severity of the disease depends on the mutation, and LDLR null mutations produce the most severe phenotype. ${ }^{3615-18}$

\section{DIAGNOSIS AND CLINICAL MANAGEMENT OF THE DISEASE}

Given the severity of $\mathrm{FH}$, particularly the $\mathrm{HoFH}$ form that affects children during the first decade of life, early detection is critical for mitigating the genetically induced hypercholesterolaemia effects in these patients. Thus, optimising the diagnosis of children affected by this pathology is of utmost importance.

At the clinical level, HoFH must be suspected with untreated plasma LDL-C levels $>13 \mathrm{mmol} / \mathrm{L}$ in non-treated patients or $>8 \mathrm{mmol} / \mathrm{L}$ in individuals treated with standard cholesterol-lowering therapies, according to European Atherosclerosis Society guidelines. ${ }^{3}$ However, lower plasma LDL-C in children or treated patients does not exclude $\mathrm{HoFH}$. 


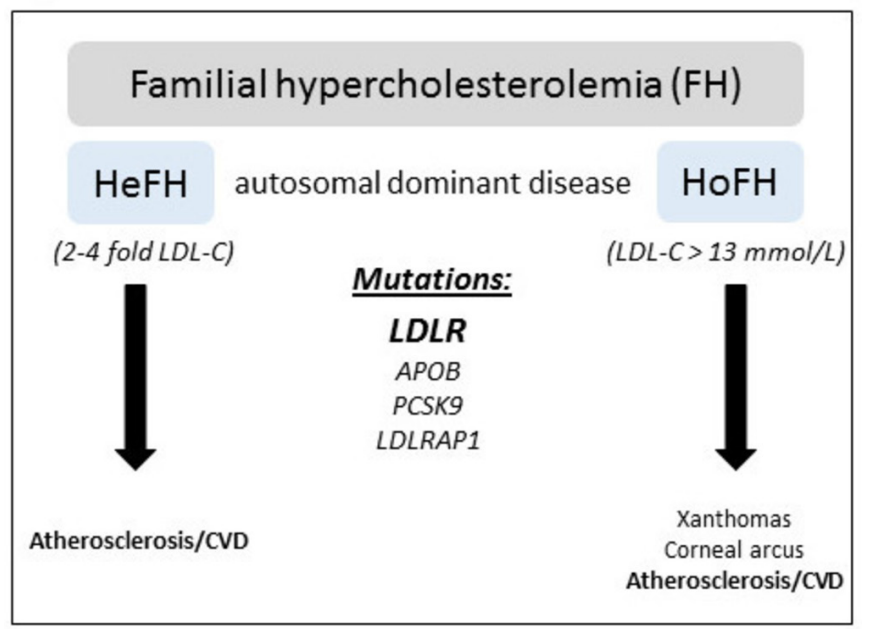

Figure 1 Schematic representation of $\mathrm{FH}$ disease. $\mathrm{FH}$ is an autosomal dominant disease characterised by elevated serum LDL-C levels as a result of mutations in the genes involved in cholesterol clearance, such as $A P O B$, $P C S K 9, \angle D L R A P 1$ and $L D L R$. Mutations in the $L D L R$ explain $80 \%-90 \%$ of the cases. The HoFH shows LDL-C levels $>13 \mathrm{mmol} / \mathrm{L}$. Therefore, HoFH patients present a higher risk of developing severe CVD than $\mathrm{HeFH}$ patients. CVD, cardiovascular disease; $\mathrm{FH}$, familial hypercholesterolaemia; $\mathrm{HeFH}$, heterozygous familial hypercholesterolaemia; ; HoFH, homozygous $\mathrm{f}$ amilial hypercholesterolaemia; LDL-C, low-density lipoprotein cholesterol; $A P O B$, apolipoprotein $B ; P C S K 9$, proprotein convertase subtilisin/kexin type 9; $L D L R A P 1$, low-density lipoprotein receptor adaptor protein $1 ; L D L R$, low-density lipoprotein receptor.

The presence of xanthomas in children $<10$ years old and/or high LDL-C levels without treatment in both parents is suggestive of the disease. However, these features do not always allow for the differentiation between homozygous and heterozygous individuals due to different grade in the severity of the disease, which is critical given the severity and the poor response to traditional lipid-lowering therapies in $\mathrm{HoFH}$.

Genetic testing is mandatory to confirm a definite $\mathrm{HoFH}$ diagnosis. HoFH has been confirmed by mutations in both copies of $L D L R,{ }^{4} A P O B^{8}$ and PCSK9. ${ }^{9}{ }^{10}$ Additionally, recessive autosomal $\mathrm{FH}$ has been described in patients with mutations on both LDLRAP1 alleles. ${ }^{11}$ Nevertheless, genetic confirmation is not always possible, potentially due to additional genes involved in $\mathrm{FH}$ development. ${ }^{2}$ Other factors that may be at play when a mutation is not found include (1) mutation type that is not detectable with the laboratory method (eg, copy number variation) and (2) polygenic hypercholesterolaemia, which is seen in $20 \%-30 \%$ of cases of suspected HeFH. Moreover, genetic classification of the disease may be challenging given the possibility of two functional mutations in the same gene, which can be in the same allele (compound heterozygous in cis), usually associated with the HeFH phenotype, or in two different alleles (compound heterozygous in trans), leading to the HoFH phenotype. Additionally, mutations in two different $L D L R$-associated genes are found in double heterozygous patients. In patients with a clinical diagnosis of $\mathrm{FH}$ in whom a specific mutation cannot be found, it is likely that the disease presents a polygenic aetiology. ${ }^{19}$

\section{CURRENT THERAPIES}

Whereas HeFH patients are successfully treated with standard cholesterol-lowering therapies, these therapies are not usually effective for $\mathrm{HoFH}$ individuals. ${ }^{20} 21$ Although statins can be considered the foundation of treatment for $\mathrm{HoFH},{ }^{22-26}$ even the highest doses of the most potent statins (ie, atorvastatin and rosuvastatin) cause only a modest reduction in LDL-C plasma levels (10\%-25\% reduction) due to the lack of functional receptors that can be upregulated in HoFH. A combined therapy of statins with the cholesterol absorption inhibitor ezetimibe could achieve reductions of $30 \%-35 \%$ in circulating LDL-C levels. Although this may seem like a considerable reduction, taking into account that $\mathrm{HoFH}$ patients can present with untreated plasma levels of LDL-C $>13 \mathrm{mmol} / \mathrm{L}$, this reduction results in an achieved LDL-C that still markedly exceeds ideal target levels, that is, LDL-C $<2.5 \mathrm{mmol} / \mathrm{L}$ in adults, $<3.5 \mathrm{mmol} / \mathrm{L}$ in children and $<1.8 \mathrm{mmol} / \mathrm{L}$ in patients with clinical atherosclerotic CVD. ${ }^{2}$ The addition of other lipid-lowering drugs, such as fibrates or bile acid-binding resins, showed no further reduction in LDL-C levels. The recently approved monoclonal PCSK9 inhibitors have a very limited effect on LDL-C levels in receptor-negative $\mathrm{HoFH}$ patients, ${ }^{27}$ although they are able to reduce LDL-C by $25 \%$ in patients who have at least one receptor-defective allele. Therefore, other strategies must be considered to prevent atherosclerotic CVD in $\mathrm{HoFH}$ patients, including newly approved pharmacologic modalities, such as lomitapide and mipomersen. These drugs are focused on inhibiting the microsomal triglyceride transfer protein ${ }^{28}$ or reducing apoB synthesis, ${ }^{29}$ respectively, therefore, interfering with the production of apoB-carrying lipoprotein rather than increasing its blood elimination. Although these drugs have shown promising results in reducing plasma LDL-C levels in HoFH patients, their degree of efficiency correlates with clinically relevant side effects, such as an increase in liver fat content, ${ }^{30} 31$ gastrointestinal distress and malabsorption or, in the case of mipomersen, skin reactions. Additionally, both human genetic analyses and preclinical studies have suggested that ANGPTL3 inhibition reduces LDL-C levels independently of LDLR function. ${ }^{32}$ Interestingly, the administration of Evinacumab, an ANGPTL3-blocking antibody, reduced the LDL-C levels in nine HoFH patients by a mean of $49 \%$ after 4 weeks of treatment, ${ }^{33}$ although patients with the most severe forms of disease did not reach therapeutic objectives.

Apart from the drug-based approaches, liver transplantation in $\mathrm{HoFH}$ has shown reductions in LDL-C plasma levels of up to $80 \% .^{34-36}$ However, this therapeutic option is practically in disuse given its associated issues, such as surgical complications, post-transplant mortality, shortage of donors and the need for lifelong treatment with immunosuppressants. ${ }^{37}$

Thus, pharmacologic-treated $\mathrm{HoFH}$ patients are commonly subjected to weekly or biweekly lipid apheresis. ${ }^{38-42}$ Using this treatment, it is possible to reduce LDL-C plasma levels almost to the levels found in healthy individuals. Increasing clinical evidence suggests that prolonged LDL apheresis may contribute to plaque reduction and/or stabilisation and improves its prognosis. ${ }^{43}$ Although LDL apheresis is the best current therapeutic approach for severe HoFH patients, it requires specialised hospital infrastructure with a substantial budget and has a great personal impact, confining patients to a lifelong extracorporeal LDL clearance. Moreover, the availability of this treatment is limited in many countries. Therefore, the development of alternative approaches is eagerly awaited to mitigate the lethality of this disease.

\section{GENE THERAPY FOR HOFH}

Given that $\mathrm{HoFH}$ is mainly due to mutations in the $L D L R$, restoring LDLR function using gene therapy may be a useful strategy to mitigate the effects of the disease. Increasing evidence supports the idea that introducing functional copies of the LDLR gene reduces LDL-C plasma levels and reduces the negative cardiovascular effects 


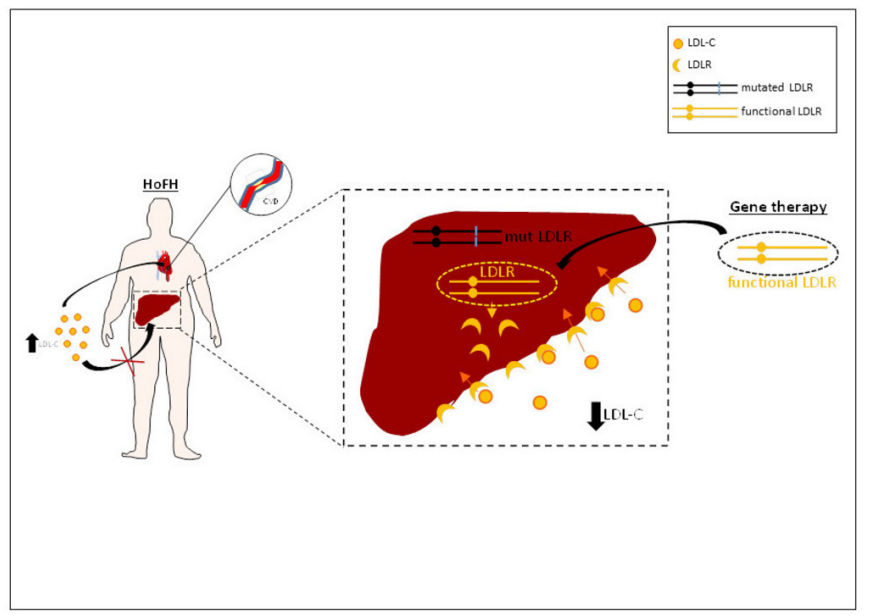

Figure 2 Gene therapy for HoFH. In HoFH patients, LDL-C cannot be uptaken by the liver, thus increasing plasma LDL-C levels and risk for CVD. Insertion of functional copies of the $L D L R$ gene in the liver increases hepatic LDL-C clearance and reduces plasma LDL-C. CVD, cardiovascular disease; HoFH, homozygous familial hypercholesterolaemia; LDL-C, lowdensity lipoprotein cholesterol; LDLR, low-density lipoprotein receptor.

of $\mathrm{HoFH}$ (figure 2). Nevertheless, not all forms of gene therapy tried in the past were efficacious. Next, we will review the scientific evolution of gene therapy for HoFH from the initial approaches using ex vivo transduction with retroviruses in the $1990 \mathrm{~s}^{44}$ and the first clinical trial based in this technology in $1995^{45}$ to the in vivo adenoviral $^{46-50}$ and helper-dependent adenoviral (HD-Ad) transduc$\operatorname{tion}^{51-53}$ and the development of the adeno-associated virus (AAV) vectors $^{54-60}$ that have allowed the current clinical trial in development since 2016 (figure 3). The limitations of these strategies and their replacement by advanced approaches will also be discussed. Additionally, we will briefly discuss future perspectives based on the clustered regularly interspaced short palindromic repeat/CRISPR-associated 9 (CRISPR/Cas9) technology for genome editing. ${ }^{61}$

\section{Origins and evolution of gene therapy for HoFH}

Retrovirus-mediated gene transfer

Autologous hepatocytes that were genetically modified by recombinant retroviruses containing a functional human $L D L R$ gene were transplanted into livers from Watanabe heritable hyperlipidaemic (WHHL) rabbits via portal vein infusion. ${ }^{44}$ Transgene expression decreased total serum cholesterol levels from the second to the sixth day after transplantation, obtaining a maximum reduction of $70 \%$ on the third day. After this peak, total serum cholesterol levels progressively increased, reaching the pretreatment levels from the seventh day after the hepatocyte transplant. ${ }^{44}$ Using this approach, Grossman et al performed the first human pilot gene therapy clinical trial to transfer human $L D L R$-expressing retrovirus-transduced hepatocytes to the liver of five $\mathrm{HoFH}$ patients. ${ }^{45}$ Transgene expression was detected in a limited number of hepatocytes in liver biopsies 4 months after treatment. A modest and variable reduction in the LDL-C levels $(6 \%-25 \%)$ was found in three of the five patients enrolled, potentially due to the low efficiency of the transgene transference $^{45}$. Thus, these data ruled out the clinical application of retroviral-based vectors in gene therapy without consistent and sustained gene transfer.

\section{Adenovirus-mediated gene transfer}

To avoid problems related to ex vivo approaches, such as failure of cell engraftment, a direct in vivo approach using recombinant adenovirus encoding the human $L D L R$ was used in $L d l r^{-/}$mice. ${ }^{46}$ The adenovirus-mediated $L D L R$ overexpression increased very low-density lipoprotein (VLDL) clearance and reduced the elevated intermediate-density lipoprotein (IDL)/LDL plasma levels in the $\mathrm{Ldlr}^{-/}$mice. ${ }^{46}$ Similar results showing reduced serum cholesterol levels were found in WHHL rabbits treated with adenovirus overexpressing the $L D L R$ gene. ${ }^{47} 48$ In addition to $L D L R$, the overexpression of the VLDL receptor (VLDLR) by adenovirus in the liver of $\mathrm{Ldlr}^{-/}$mice also reduced total cholesterol levels between twofold and fourfold in these animals. ${ }^{49} 50$ Nevertheless, similar to the retrovirus vectors, the adenoviral vectors led to a non-permanent transgene expression due to the immunogenicity of these viruses.

\section{HD-Ad-mediated gene transfer}

To increase adenovirus-mediated transgene persistence, Oka et al overexpressed VLDLR in the livers of $\mathrm{Ldlr}^{-/-}$mice using HD-Ad vectors. ${ }^{51}$ Transgene expression persisted after 6 months of virus infusion, which was in line with the reduction in plasma cholesterol levels and an almost complete prevention of atherosclerotic aorta lesions in these animals. ${ }^{51}$ However, since VLDLR mediates the uptake of

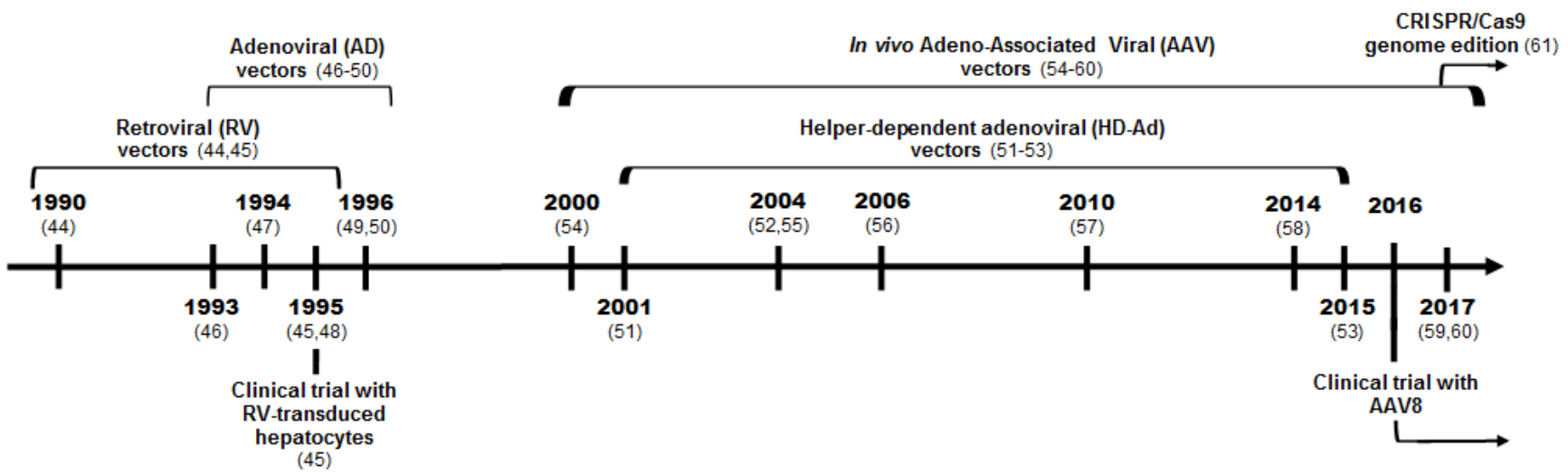

Figure 3 Timeline showing the historic overview of gene therapy research for the treatment of HoFH. The time period during which each approach was used before it was replaced by more advanced technologies is indicated. References for the publications are indicated under each year. The clinical trials with retroviruses (1995) and AAV (2016) are indicated below. AD, adenoviral; RV, retroviral; AAV, adeno-associated viral; HD-Ad, helper-dependent adenoviral; CRISPR/Cas9, clustered regularly interspaced short palindromic repeat/CRISPR-associated 9; . 


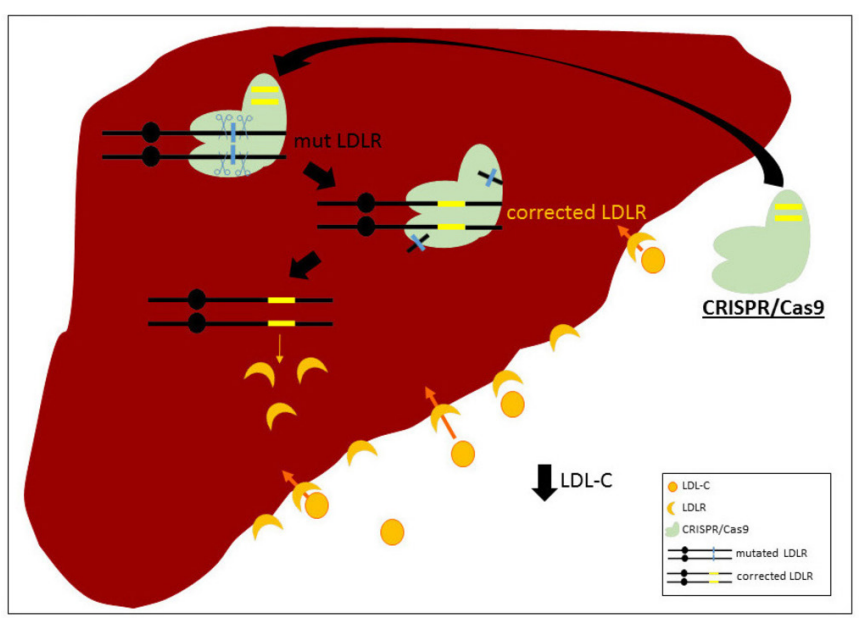

Figure 4 CRISPR/Cas9 technology for HoFH genetic correction. Using CRISPR/Cas9 technology for gene edition is potentially feasible to repair specific mutations inside endogenous $L D L R$ in HoFH patients. CRISPR/Cas9, clustered regularly interspaced short palindromic repeat/CRISPR-associated 9; HoFH, homozygous familial hypercholesterolaemia; LDL-C, low-density lipoprotein cholesterol; LDLR, low-density llipoprotein cholesterol receptor.

only IDL, not LDL, VLDLR overexpression is not considered for clinical application. Additionally, the effect of $L D L R$ overexpression by $\mathrm{HD}$-Ad in lowering the plasma cholesterol levels was greater than that achieved by VLDLR overexpression. ${ }^{52}$ However, although LDLR overexpression by $\mathrm{HD}$-Ad in rhesus macaques heterozygous for a nonsense mutation in the $L D L R$ gene $\left(L D L R^{+/}\right)$effectively reversed hypercholesterolaemia, the heterogeneous and unsustained long-term response precludes its future application. ${ }^{53}$

\section{AAV precursors of the current gene therapy}

Since 2000, recombinant AAV vectors have been available for long-term persistent expression. ${ }^{54} 6263$ However, not all AAV serotypes are equally efficient. LDLR overexpression using serotype 2 (AAV2) showed a low transduction efficiency and the loss of liver-associated vector DNA in fat-fed $\mathrm{Ldlr}^{-/-}$mice. ${ }^{54}$ Nevertheless, the identification of novel capsid AAVs ${ }^{64}$ has overcome some of the deficiencies related to AAV2. Specifically, serotype 8 (AAV8) has shown high transduction efficiency in the livers of mouse and dog models, with reduced pre-existing humoral immunity and $\mathrm{T}$ cell response to the capsid. ${ }^{566566}$ Additionally, the AAV8 vectors were well tolerated in $L D L R^{+/-}$macaques, showing only sporadic mild histopathology, low level and transient transaminase elevations, and an adaptive immune response restricted to early time points. ${ }^{60}$ Using these new AAV vectors, a long-term correction of the metabolic defect was achieved in several HoHF animal models. Compared with AAV2, chimeric AAV2/7 and AAV2/8 vectors encoding the common human apolipoprotein $\mathrm{E}(A P O E) \mathrm{E} 3$ isoform reduced cholesterol levels and prevented atherosclerosis in chow-fed ApoE ${ }^{-/-}$mice. $^{56}$ Similarly, whereas AAV7 and AAV8 vectors encoding human $L D L R$ achieved nearly complete normalisation of serum lipids and prevented severe atherosclerosis in $\mathrm{Ldlr}^{--}$mice fed a high-fat diet, the AAV2 vector constructs showed only partial lipid correction and a modest atherosclerosis improvement. ${ }^{55}$ The AAV8 vectors were further explored in a humanised model of $\mathrm{HoFH}$, the $\mathrm{Ldlr}$ ${ }^{\prime}$ ApoBec $1^{-/}$mice, which develop atherogenesis with a chow diet. ${ }^{57}$ Delivering the mouse $L d l r$ gene by AAV8 to these animals reduced plasma cholesterol and non-HDL cholesterol levels and achieved an $87 \%$ plaque regression compared with the animals treated with the AAV8-null vector. ${ }^{57}$ To test the AAV8 vectors in a model more closely resembling human $\mathrm{HoFH}$, the $L d l r^{-/} A p o B e c 1^{-/} h A p o B$ mice were generated to simulate the in vivo interactions between human LDLR and human ApoB100. ${ }^{67}$ AAV8 encoding the human LDLR significantly corrected hypercholesterolaemia in the $L d l r^{--} A p o-$ $B e c 1^{-1-} h A p o B^{67}$ mice. The effect of the AAV8-LDLR vectors on cholesterol reduction was greater when transducing $L D L R$ variants that expressed LDLR proteins resistant to PCSK9 and/or inducible degrader of LDLR (IDOL) in both in vitro and in vivo models overexpressing these proteins. ${ }^{58}$

\section{AAV-mediated gene transfer limitations}

Although AAV has emerged as a powerful tool for long-term persistent transgene expression, it is worth noting that none of the gene therapy platforms used previously in the clinic based on AAV vectors have achieved a complete reversal of the disease phenotype. Additionally, human hepatocytes are less efficiently transfected by AAV vectors than murine hepatocytes. ${ }^{6869}$ More importantly, constitutive expression of the LDLR in experimental models results in cytotoxicity due to excessive lipid internalisation. ${ }^{47} 7071$ While hepatocyte-specific promoters do not appear to show lipotoxic effects, ${ }^{67} 72$ given the complexity of LDL metabolism and LDLR physiological regulation, the lack of transgene expression regulation could lead to unexpected longterm consequences, such as the pathological accumulation of lipids and cholesterol in hepatocytes. ${ }^{70}$

\section{Present advancements of gene therapy for HoFH: the AAV8. TBG.hLDLR clinical trial}

As mentioned above, most of the gene therapy approaches for HoFH show several limitations that have impeded its clinical application. Ex vivo approaches have shown problems related to cell engraftment. Transgene transference based on both retrovirus and adenovirus vectors have failed to achieve permanent expression due to the immunogenicity of these particles. Although AAV leads to long-term persistent expression, not all serotypes are equally efficient for human hepatocyte transduction. Therefore, most of these approaches have been ruled out for their clinical inadequacies.

However, most of these concerns have been overcome with AAV8 vectors. The safety of these vectors for $L D L R$ gene therapy was assessed in non-clinical pharmacological/toxicological studies in both $\mathrm{Ldlr}^{-/}$ApoBec1 $1^{-/} \mathrm{mice}^{59}$ and $L_{D L R^{+l} \text { Rhesus Macaques }}{ }^{60}$ prior to initiation of a phase I clinical trial. In these studies, LDLR expression was driven by a liver-specific thyroxine-binding globulin (TBG) promoter (AAV8.TBG.mLDLR) to drive sustained $L D L R$ expression in the liver. Based on these advances, after more than two decades from the first HoFH gene therapy clinical trial, ${ }^{45}$ phase $\mathrm{I} / \mathrm{II}$ a of a new human clinical trial was started in March 2016 to test the AAV8.TBG.hLDLR (NCT02651675), which is currently in development. This clinical trial enrolled $12 \mathrm{HoFH}$ individuals with follow-up up to 5 years after receiving a recombinant $L D L R$-expressing AAV8 vector. The primary outcome of this study involved the assessment of vector-related adverse effects by 52 weeks following administration. The secondary outcomes include the fractional catabolic rate of LDL apoB, the percentage of change in LDL-C and lipid parameters at 12 weeks compared 
with baseline, and the percentage change in lipid parameters at 260 weeks compared with baseline. Data from this clinical trial are eagerly awaited by the scientific community and HoFH patients.

\section{Future perspectives in gene therapy for HoFH}

Transplantation of autologous genetically modified hepatocyte-like cells derived from induced pluripotent stem cell

An alternative option to hepatocyte transplantation may be the autologous transplantation of hepatocyte-like genetically corrected cells derived from induced pluripotent stem cells (iPSCs). Transfecting the iPSCs of an HoFH patient with a plasmid containing the $L D L R$ allows for the formation of hepatocyte-like cells that are able to uptake the extracellular LDL. ${ }^{73}$ Interestingly, this response was regulated by lovastatin and sterol, thereby showing a reestablishment in the LDL physiological regulation. ${ }^{74}$ However, although promising, the hepatocyte-like derived iPSCs transplant technology that was used is unlikely to be used in a clinical setting given the potential risk of tumourigenesis. ${ }^{75}$

\section{Gene editing with CRISPR/Cas9: expectations and limitations}

Experimental approaches using transgene-containing $L D L R$ genomic regulatory elements in combination with statins ${ }^{76}$ or small interfering RNA oligonucleotides and miRNA against 3-hydroxy-3-methylglutaryl-CoA reductase ${ }^{77}$ enhanced transgene expression and activity. Therefore, combining gene therapy with strategies aimed at obtaining physiological/pharmacological transgene regulation would minimise the risk of unwanted gene therapy effects. Furthermore, the recent development of technology based on CRISPR/Cas9 for genome editing has opened the door to directly repair specific mutations in the endogenous $L D L R$ gene, thereby giving rise to a functional gene copy subjected to physiological regulation (figure 4). Using this technology, Omer et al permanently corrected a 3-base pair homozygous deletion in LDLR exon 4 with $<5 \%$ receptor activity ${ }^{78}$ in iPSCs derived from skin fibroblasts of an HoFH patient. ${ }^{61}$ The hepatocyte-like cells derived from the corrected iPSCs showed physiologic control of LDLR expression and restored receptor-mediated LDL endocytosis and cholesterol metabolism. ${ }^{61}$ Nevertheless, several technical challenges must be refined before seriously considering CRISPR/Cas9 gene editing as a realistic therapeutic option for the treatment of HoFH. Although the use of modified Cas9 nickase with paired single-guide RNAs enhances the likelihood for homology-directed repair $(\mathrm{HDR})^{79} 80$ and reduces off-target mutations, ${ }^{79} 81$ indels are still found within the corrected gene. ${ }^{61}$ Additionally, other off-target modifications may occur in non-predicted sites. Furthermore, after the selection of the suitable corrected clone, there are still the aforementioned problems in cell engraftment and/or the potential risk of tumourigenesis. ${ }^{75} \mathrm{~A}$ direct CRISPR/Cas9 in vivo approach is potentially feasible. In fact, this technology has already been used for hepatic gene editing in adult mice to knock out a gene. ${ }^{82}$ However, gene disruption was achieved by random indels within the targeted gene. Specific repair of point mutations by HDR seems difficult in differentiated somatic cells. Thus, further research is warranted to develop CRISPR/Cas9based strategies to specifically edit single mutations in differentiated cells of adult individuals and to minimise any off-target unwanted effects.

\section{CONCLUSIONS}

In conclusion, effective therapies to definitively resolve the most severe forms of $\mathrm{HoFH}$ are currently needed. HoFH is an autosomal dominant disease commonly caused by mutations in the $L D L R$ gene and can lead to severe CVD in the first decade of life due to the inability to clear circulating LDL-C levels. Although LDL-apheresis in patients using a traditional combination lipid-lowering therapy is able to reduce LDL-C levels to near those found in healthy individuals, this approach does not cure the disease, causes patient discomfort and requires specialised personnel and facilities. Therefore, additional therapies aimed at curing the most severe forms of this disease are eagerly awaited. Given the genetic nature of $\mathrm{HoFH}$, research has focused on gene therapy to restore LDLR function. Numerous experimental approaches have shown promising results in delivering functional copies of the $L D L R$ gene to several animal models of the disease, and these findings have encouraged the onset of the first clinical trials. Additionally, the recent development of CRISPR/Cas9 technology for gene editing has opened the door to correct the specific mutations causing the disease in the endogenous $L D L R$ gene, thereby restoring the $L D L R$ function under physiological regulation. Nevertheless, there is still a long way to go before using this approach in clinic, and several issues have to be refined before seriously considering CRISPR/Cas9 technology as a realistic therapeutic option for HoFH treatment.

Contributors RR-C and LM have designed, drafted and revised the article. RR-C and LM have approved the final version of the article. RR-C has submitted the article.

Funding This work was financially supported by a grant from ISCIII, Madrid, Spain (PI15/00627), and from the CIBER in Diabetes and Associated Metabolic Disorders (CB07/08/0028).

Competing interests None declared.

Patient consent for publication Not required.

Provenance and peer review Not commissioned; externally peer reviewed.

ORCID iD

Ricardo Rodriguez-Calvo http://orcid.org/0000-0001-7513-0983

\section{REFERENCES}

1 Gidding SS. The complexities of homozygous familial hypercholesterolemia management. Pediatr Transplant 2016;20:1020-1.

2 Nordestgaard BG, Chapman MJ, Humphries SE, Ginsberg HN, Masana L, Descamps OS, Wiklund O, Hegele RA, Raal FJ, Defesche JC, Wiegman A, Santos RD, Watts GF, Parhofer KG, Hovingh GK, Kovanen PT, Boileau C, Averna M, Borén J, Bruckert E, Catapano AL, Kuivenhoven JA, Pajukanta P, Ray K, Stalenhoef AF, Stroes E, Taskinen MR, Tybjærg-Hansen A. Familial hypercholesterolaemia is underdiagnosed and undertreated in the general population: guidance for clinicians to prevent coronary heart disease: consensus statement of the European atherosclerosis society. Eur Heart J 2013;34:3478-90.

3 Cuchel M, Bruckert E, Ginsberg HN, Raal FJ, Santos RD, Hegele RA, Kuivenhoven JA, Nordestgaard BG, Descamps OS, Steinhagen-Thiessen E, Tybjærg-Hansen A, Watts GF, Averna M, Boileau C, Borén J, Catapano AL, Defesche JC, Hovingh GK, Humphries SE, Kovanen PT, Masana L, Pajukanta P, Parhofer KG, Ray KK, Stalenhoef AF, Stroes E, Taskinen MR, Wiegman A, Wiklund O, Chapman MJ. Homozygous familial hypercholesterolaemia: new insights and guidance for clinicians to improve detection and clinical management. A position paper from the Consensus Panel on Familial Hypercholesterolaemia of the European Atherosclerosis Society. Eur Heart J 2014;35:2146-57.

4 Goldstein JL HH, Brown MS. Familial hypercholesterolemia. In: Scriver CR BA, Sly WS, Valle D editores, The metabolic and molecular bases of inherited disease. 8th edn New York: McGraw-Hill Information Services Company, 2001:2863-913.

5 Austin MA, Hutter CM, Zimmern RL, Humphries SE. Genetic causes of monogenic heterozygous familial hypercholesterolemia: a HuGE prevalence review. Am J Epidemiol 2004; 160:407-20.

6 Sirtori CR, Pavanello C, Bertolini S. Microsomal transfer protein (MTP) inhibition-a novel approach to the treatment of homozygous hypercholesterolemia. Ann Med 2014;46:464-74.

7 Kolovou G, Vasiliadis I, Gontoras N, Kolovou V, Hatzigeorgiou G. Microsomal transfer protein inhibitors, new approach for treatment of familial hypercholesterolemia, review of the literature, original findings, and clinical significance. Cardiovasc Ther 2015;33:71-8 
8 Soria LF, Ludwig EH, Clarke HR, Vega GL, Grundy SM, McCarthy BJ. Association between a specific apolipoprotein B mutation and familial defective apolipoprotein B-100. Proc Natl Acad Sci U S A 1989;86:587-91.

9 Abifadel M, Varret M, Rabès JP, Allard D, Ouguerram K, Devillers M, Cruaud C, Benjannet S, Wickham L, Erlich D, Derré A, Villéger L, Farnier M, Beucler I, Bruckert E, Chambaz J, Chanu B, Lecerf JM, Luc G, Moulin P, Weissenbach J, Prat A, Krempf M, Junien C, Seidah NG, Boileau C. Mutations in PCSK9 cause autosomal dominant hypercholesterolemia. Nat Genet 2003:34:154-6.

10 Palacios L, Grandoso L, Cuevas N, Olano-Martín E, Martinez A, Tejedor D, Stef M. Molecular characterization of familial hypercholesterolemia in Spain. Atherosclerosis 2012;221:137-42.

11 Varret M, Abifadel M, Rabès JP, Boileau C. Genetic heterogeneity of autosomal dominant hypercholesterolemia. Clin Genet 2008;73:1-13.

12 lacocca MA, Chora JR, Carrié A, Freiberger T, Leigh SE, Defesche JC, Kurtz CL, DiStefano MT, Santos RD, Humphries SE, Mata P, Jannes CE, Hooper AJ, Wilemon KA Benlian P, O'Connor R, Garcia J, Wand H, Tichy L, Sijbrands EJ, Hegele RA, Bourbon M, Knowles JW. ClinVar database of global familial hypercholesterolemia-associated DNA variants. Hum Mutat 2018;39:1631-40

13 Berberich AJ, Hegele RA. The complex molecular genetics of familial hypercholesterolaemia. Nat Rev Cardiol 2019;16:9-20.

14 Defesche JC, Gidding SS, Harada-Shiba M, Hegele RA, Santos RD, Wierzbicki AS. Familial hypercholesterolaemia. Nat Rev Dis Primers 2017;3:17093.

15 Raper A, Kolansky DM, Sachais BS, Meagher EA, Baer AL, Cuchel M. Long-term clinical results of microsomal triglyceride transfer protein inhibitor use in a patient with homozygous familial hypercholesterolemia. J Clin Lipido/ 2015;9:107-12.

16 Cuchel M, Blom DJ, Averna MR. Clinical experience of lomitapide therapy in patients with homozygous familial hypercholesterolaemia. Atheroscler Supp/ 2014;15:33-45.

17 Davis KA, Miyares MA. Lomitapide: A novel agent for the treatment of homozygous familial hypercholesterolemia. Am J Health Syst Pharm 2014;71:1001-8.

18 Perry CM. Lomitapide: a review of its use in adults with homozygous familial hypercholesterolemia. Am J Cardiovasc Drugs 2013;13:285-96.

19 Sharifi M, Futema M, Nair D, Humphries SE. Genetic Architecture of Familial Hypercholesterolaemia. Curr Cardiol Rep 2017;19:44.

20 Sjouke B, Kusters DM, Kindt I, Besseling J, Defesche JC, Sijbrands EJ, Roeters van Lennep JE, Stalenhoef AF, Wiegman A, de Graaf J, Fouchier SW, Kastelein JJ, Hovingh GK. Homozygous autosomal dominant hypercholesterolaemia in the Netherlands: prevalence, genotype-phenotype relationship, and clinical outcome. Eur Heart 2015;36:560-5.

21 Wiegman A, Gidding SS, Watts GF, Chapman MJ, Ginsberg HN, Cuchel M, Ose L, Averna M, Boileau C, Borén J, Bruckert E, Catapano AL, Defesche JC, Descamps OS, Hegele RA, Hovingh GK, Humphries SE, Kovanen PT, Kuivenhoven JA, Masana L, Nordestgaard BG, Pajukanta P, Parhofer KG, Raal FJ, Ray KK, Santos RD, Stalenhoef AF, Steinhagen-Thiessen E, Stroes ES, Taskinen MR, Tybjærg-Hansen A, Wiklund O. Familial hypercholesterolaemia in children and adolescents: gaining decades of life by optimizing detection and treatment. Eur Heart J 2015;36:2425-37.

22 Raal FJ, Pilcher GJ, Illingworth DR, Pappu AS, Stein EA, Laskarzewski P, Mitchel $Y B$, Melino MR. Expanded-dose simvastatin is effective in homozygous familial hypercholesterolaemia. Atherosclerosis 1997;135:249-56.

23 Raal FJ, Pappu AS, Illingworth DR, Pilcher GJ, Marais AD, Firth JC, Kotze MJ, Heinonen TM, Black DM. Inhibition of cholesterol synthesis by atorvastatin in homozygous familial hypercholesterolaemia. Atherosclerosis 2000;150:421-8.

24 Marais AD, Raal FJ, Stein EA, Rader DJ, Blasetto J, Palmer M, Wilpshaar W. A dosetitration and comparative study of rosuvastatin and atorvastatin in patients with homozygous familial hypercholesterolaemia. Atherosclerosis 2008;197:400-6.

25 Marais AD, Blom DJ, Firth JC. Statins in homozygous familial hypercholesterolemia. Curr Atheroscler Rep 2002;4:19-25.

26 Yamamoto A, Harada-Shiba M, Kawaguchi A, Oi K, Kubo H, Sakai S, Mikami Y, Imai T, Ito T, Kato H, Endo M, Sato I, Suzuki Y, Hori H. The effect of atorvastatin on serum lipids and lipoproteins in patients with homozyous familial hypercholesterolemia undergoing LDL-apheresis therapy. Atherosclerosis 2000;153:89-98.

27 Raal FJ, Honarpour N, Blom DJ, Hovingh GK, Xu F, Scott R, Wasserman SM, Stein EA. Inhibition of PCSK9 with evolocumab in homozygous familial hypercholesterolaemia (TESLA Part B): a randomised, double-blind, placebo-controlled trial. Lancet 2015:385:341-50

28 Cuchel M, Bloedon LT, Szapary PO, Kolansky DM, Wolfe ML, Sarkis A, Millar JS, Ikewaki K, Siegelman ES, Gregg RE, Rader DJ. Inhibition of microsomal triglyceride transfer protein in familial hypercholesterolemia. N Engl J Med 2007;356:148-56

29 Crooke ST, Geary RS. Clinical pharmacological properties of mipomersen (Kynamro) a second generation antisense inhibitor of apolipoprotein B. Br J Clin Pharmacol 2013:76:269-76.

30 Raal FJ, Santos RD, Blom DJ, Marais AD, Charng MJ, Cromwell WC, Lachmann RH, Gaudet D, Tan JL, Chasan-Taber S, Tribble DL, Flaim JD, Crooke ST. Mipomersen, an apolipoprotein B synthesis inhibitor, for lowering of LDL cholesterol concentrations in patients with homozygous familial hypercholesterolaemia: a randomised, doubleblind, placebo-controlled trial. Lancet 2010;375:998-1006.

31 Cuchel M, Meagher EA, du Toit Theron H, Blom DJ, Marais AD, Hegele RA, Averna MR, Sirtori CR, Shah PK, Gaudet D, Stefanutti C, Vigna GB, Du Plessis AM, Propert KJ, Sasiela WJ, Bloedon LT, Rader DJ. Efficacy and safety of a microsomal triglyceride transfer protein inhibitor in patients with homozygous familial hypercholesterolaemia: a single-arm, open-label, phase 3 study. Lancet 2013;381:40-6.

32 Dewey FE, Gusarova V, Dunbar RL, O'Dushlaine C, Schurmann C, Gottesman O, McCarthy S, Van Hout CV, Bruse S, Dansky HM, Leader JB, Murray MF, Ritchie MD, Kirchner HL, Habegger L, Lopez A, Penn J, Zhao A, Shao W, Stahl N, Murphy AJ, Hamon S, Bouzelmat A, Zhang R, Shumel B, Pordy R, Gipe D, Herman GA, Sheu WHH, Lee IT, Liang KW, Guo X, Rotter JI, Chen YI, Kraus WE, Shah SH, Damrauer S, Small A, Rader DJ, Wulff AB, Nordestgaard BG, Tybjærg-Hansen A, van den Hoek AM, Princen HMG, Ledbetter DH, Carey DJ, Overton JD, Reid JG, Sasiela WJ, Banerjee P, Shuldiner AR, Borecki IB, Teslovich TM, Yancopoulos GD, Mellis SJ, Gromada J, Baras A. Genetic and Pharmacologic Inactivation of ANGPTL3 and cardiovascular disease. N Eng/ J Med 2017:377:211-21.

33 Gaudet D, Gipe DA, Pordy R, Ahmad Z, Cuchel M, Shah PK, Chyu KY, Sasiela WJ, Chan KC, Brisson D, Khoury E, Banerjee P, Gusarova V, Gromada J, Stahl N, Yancopoulos GD, Hovingh GK. ANGPTL3 Inhibition in Homozygous Familial Hypercholesterolemia. N Engl J Med 2017;377:296-7.

34 López-Santamaria M, Migliazza L, Gamez M, Murcia J, Diaz-Gonzalez M, Camarena C, Hierro L, De la Vega A, Frauca E, Diaz M, Jara P, Tovar J. Liver transplantation in patients with homozygotic familial hypercholesterolemia previously treated by end-toside portocaval shunt and ileal bypass. J Pediatr Surg 2000;35:630-3.

35 Castilla Cabezas JA, López-Cillero P, Jiménez J, Fraga E, Arizón JM, Briceño J, Solórzano G, De la Mata M, Pera C. Role of orthotopic liver transplant in the treatment of homozygous familial hypercholesterolemia. Rev Esp Enferm Dig 2000;92:601-8.

36 Valdivielso P, Escolar JL, Cuervas-Mons V, Pulpón LA, Chaparro MA, González-Santos P. Lipids and lipoprotein changes after heart and liver transplantation in a patient with homozygous familial hypercholesterolemia. Ann Intern Med 1988;108:204-6.

37 Malatack MD JJ. Liver transplantation as treatment for familial homozygous hypercholesterolemia: Too early or too late. Pediatr Transplant 2011;1:no-5.

38 Thompson GR. Managing homozygous familial hypercholesterolaemia from cradle to grave. Atheroscler Supp/ 2015;18:16-20.

39 Thompson GR, Group H-U. Recommendations for the use of LDL apheresis. Atherosclerosis 2008;198:247-55.

40 Harada-Shiba M, Arai H, Oikawa S, Ohta T, Okada T, Okamura T, Nohara A, Bujo H, Yokote K, Wakatsuki A, Ishibashi S, Yamashita S. Guidelines for the management of familial hypercholesterolemia. J Atheroscler Thromb 2012;19:1043-60.

41 Goldberg AC, Hopkins PN, Toth PP, Ballantyne CM, Rader DJ, Robinson JG, Daniels SR, Gidding SS, de Ferranti SD, Ito MK, McGowan MP, Moriarty PM, Cromwell WC, Ross $J$, Ziajka PE. Familial hypercholesterolemia: screening, diagnosis and management of pediatric and adult patients: clinical guidance from the National Lipid Association Expert Panel on Familial Hypercholesterolemia. J Clin Lipido/ 2011;5:S1-8.

42 Stefanutti C, Julius U. Lipoprotein apheresis: state of the art and novelties. Atheroscler Supp/ 2013;14:19-27.

43 Schuff-Werner $\mathrm{P}$, Fenger $\mathrm{S}$, Kohlschein P. Role of lipid apheresis in changing times. Clin Res Cardiol Supp/ 2012;7:7-14.

44 Wilson JM, Chowdhury NR, Grossman M, Wajsman R, Epstein A, Mulligan RC, Chowdhury JR. Temporary amelioration of hyperlipidemia in low density lipoprotein receptor-deficient rabbits transplanted with genetically modified hepatocytes. Proc Natl Acad Sci U S A 1990;87:8437-41.

45 Grossman M, Rader DJ, Muller DW, Kolansky DM, Kozarsky K, Clark BJ, Stein EA, Lupien PJ, Brewer HB, Raper SE. A pilot study of ex vivo gene therapy for homozygous familial hypercholesterolaemia. Nat Med 1995;1:1148-54.

46 Ishibashi S, Brown MS, Goldstein JL, Gerard RD, Hammer RE, Herz J. Hypercholesterolemia in low density lipoprotein receptor knockout mice and its reversal by adenovirus-mediated gene delivery. J Clin Invest 1993;92:883-93.

47 Kozarsky KF, McKinley DR, Austin LL, Raper SE, Stratford-Perricaudet LD, Wilson JM. In vivo correction of low density lipoprotein receptor deficiency in the Watanabe heritable hyperlipidemic rabbit with recombinant adenoviruses. The Journal of biological chemistry 1994;269:13695-702.

48 Li J, Fang B, Eisensmith RC, Li XH, Nasonkin I, Lin-Lee YC, Mims MP, Hughes A, Montgomery CD, Roberts JD. In vivo gene therapy for hyperlipidemia: phenotypic correction in Watanabe rabbits by hepatic delivery of the rabbit LDL receptor gene. $J$ Clin Invest 1995:95:768-73.

49 Kobayashi K, Oka K, Forte T, Ishida B, Teng B, Ishimura-Oka K, Nakamuta M, Chan L. Reversal of hypercholesterolemia in low density lipoprotein receptor knockout mice by adenovirus-mediated gene transfer of the very low density lipoprotein receptor. J Biol Chem 1996:271:6852-60

50 Kozarsky KF, Jooss K, Donahee M, Strauss JF, Wilson JM. Effective treatment of familia hypercholesterolaemia in the mouse model using adenovirus-mediated transfer of the VLDL receptor gene. Nat Genet 1996;13:54-62.

51 Oka K, Pastore L, Kim IH, Merched A, Nomura S, Lee HJ, Merched-Sauvage M, ArdenRiley C, Lee B, Finegold M, Beaudet A, Chan L. Long-term stable correction of lowdensity lipoprotein receptor-deficient mice with a helper-dependent adenoviral vector expressing the very low-density lipoprotein receptor. Circulation 2001;103:1274-81.

52 Nomura S, Merched A, Nour E, Dieker C, Oka K, Chan L. Low-density lipoprotein receptor gene therapy using helper-dependent adenovirus produces long-term protection against atherosclerosis in a mouse model of familial hypercholesterolemia. Gene Ther 2004;11:1540-8. 
53 Oka K, Mullins CE, Kushwaha RS, Leen AM, Chan L. Gene therapy for rhesus monkeys heterozygous for $L D L$ receptor deficiency by balloon catheter hepatic delivery of helper-dependent adenoviral vector. Gene Ther 2015;22:87-95.

54 Chen SJ, Rader DJ, Tazelaar J, Kawashiri M, Gao G, Wilson JM. Prolonged correction of hyperlipidemia in mice with familial hypercholesterolemia using an adenoassociated viral vector expressing very-low-density lipoprotein receptor. $\mathrm{Mol}$ Ther 2000;2:256-61.

55 Lebherz C, Gao G, Louboutin JP, Millar J, Rader D, Wilson JM. Gene therapy with nove adeno-associated virus vectors substantially diminishes atherosclerosis in a murine model of familial hypercholesterolemia. J Gene Med 2004;6:663-72.

56 Kitajima K, Marchadier DH, Miller GC, Gao GP, Wilson JM, Rader DJ. Complete prevention of atherosclerosis in apoE-deficient mice by hepatic human apoE gene transfer with adeno-associated virus serotypes 7 and 8. Arterioscler Thromb Vasc Biol 2006;26:1852-7.

57 Kassim SH, Li H, Vandenberghe LH, Hinderer C, Bell P, Marchadier D, Wilson A, Cromley D, Redon V, Yu H, Wilson JM, Rader DJ. Gene therapy in a humanized mouse model of familial hypercholesterolemia leads to marked regression of atherosclerosis. PLoS One 2010;5:e13424

58 Somanathan S, Jacobs F, Wang Q, Hanlon AL, Wilson JM, Rader DJ. AAV vectors expressing LDLR gain-of-function variants demonstrate increased efficacy in mouse models of familial hypercholesterolemia. Circ Res 2014;115:591-9.

59 Greig JA, Limberis MP, Bell P, Chen SJ, Calcedo R, Rader DJ, Wilson JM. Nonclinical Pharmacology/Toxicology Study of AAV8.TBG.mLDLR and AAV8.TBG.hLDLR in a Mouse model of homozygous familial hypercholesterolemia. Hum Gene Ther Clin Dev 2017;28:28-38.

60 Greig JA, Limberis MP, Bell P, Chen SJ, Calcedo R, Rader DJ, Wilson JM. Non-clinical study examining aav8.tbg.hldlr vector-associated toxicity in chow-fed wild-type and $\mathrm{LDLR}^{+/-}$rhesus macaques. Hum Gene Ther Clin Dev 2017;28:39-50.

61 Omer L, Hudson EA, Zheng S, Hoying JB, Shan Y, Boyd NL. CRISPR correction of a homozygous low-density lipoprotein receptor mutation in familial hypercholesterolemia induced pluripotent stem cells. Hepatol Commun 2017;1:886-98.

62 McCaffrey AP, Fawcett P, Nakai H, McCaffrey RL, Ehrhardt A, Pham TT, Pandey K, Xu $H$, Feuss S, Storm TA, Kay MA. The host response to adenovirus, helper-dependent adenovirus, and adeno-associated virus in mouse liver. Mol Ther 2008;16:931-41.

63 Wu Z, Asokan A, Samulski RJ. Adeno-associated virus serotypes: vector toolkit for human gene therapy. Mol Ther 2006;14:316-27.

64 Gao GP, Alvira MR, Wang L, Calcedo R, Johnston J, Wilson JM. Novel adenoassociated viruses from rhesus monkeys as vectors for human gene therapy. Proc Natl Acad Sci U SA 2002;99:11854-9.

65 Wang L, Calcedo R, Nichols TC, Bellinger DA, Dillow A, Verma IM, Wilson JM. Sustained correction of disease in naive and AAV2-pretreated hemophilia B dogs: AAV2/8-mediated, liver-directed gene therapy. Blood 2005;105:3079-86.

66 Wang L, Wang H, Bell P, McCarter RJ, He J, Calcedo R, Vandenberghe LH, Morizono H, Batshaw ML, Wilson JM. Systematic evaluation of AAV vectors for liver directed gene transfer in murine models. Mol Ther 2010;18:118-25.

67 Kassim SH, Li H, Bell P, Somanathan S, Lagor W, Jacobs F, Billheimer J, Wilson JM, Rader DJ. Adeno-associated virus serotype 8 gene therapy leads to significant lowering of plasma cholesterol levels in humanized mouse models of homozygous and heterozygous familial hypercholesterolemia. Hum Gene Ther 2013;24:19-26.
68 Lisowski L, Tay SS, Alexander IE. Adeno-associated virus serotypes for gene therapeutics. Curr Opin Pharmacol 2015;24:59-67.

69 Lisowski L, Dane AP, Chu K, Zhang Y, Cunningham SC, Wilson EM, Nygaard S, Grompe M, Alexander IE, Kay MA. Selection and evaluation of clinically relevant AAV variants in a xenograft liver model. Nature 2014;506:382-6.

70 Cichon G, Willnow T, Herwig S, Uckert W, Löser P, Schmidt HH, Benhidjeb T, Schlag PM, Schnieders F, Niedzielska D, Heeren J. Non-physiological overexpression of the low density lipoprotein receptor (LDLr) gene in the liver induces pathological intracellular lipid and cholesterol storage. J Gene Med 2004;6:166-75.

71 Heeren J, Weber W, Beisiegel U. Intracellular processing of endocytosed triglyceride-rich lipoproteins comprises both recycling and degradation. J Cell Sci 1999;112:349-59.

72 Jacobs F, Van Craeyveld E, Feng Y, Snoeys J, De Geest B. Adenoviral low density lipoprotein receptor attenuates progression of atherosclerosis and decreases tissue cholesterol levels in a murine model of familial hypercholesterolemia. Atherosclerosis 2008;201:289-97.

73 Fattahi F, Asgari S, Pournasr B, Seifinejad A, Totonchi M, Taei A, Aghdami N, Salekdeh GH, Baharvand H. Disease-corrected hepatocyte-like cells from familial hypercholesterolemia-induced pluripotent stem cells. Mol Biotechnol 2013:54:863-73.

74 Ramakrishnan VM, Yang JY, Tien KT, McKinley TR, Bocard BR, Maijub JG, Burchell PO, Williams SK, Morris ME, Hoying JB, Wade-Martins R, West FD, Boyd NL. Restoration of physiologically responsive low-density lipoprotein receptor-mediated endocytosis in genetically deficient induced pluripotent stem cells. Sci Rep 2015;5:13231.

75 Ordonez MP, Goldstein LS. Using human-induced pluripotent stem cells to model monogenic metabolic disorders of the liver. Seminars in liver disease 2012;32:298-306.

76 Hibbitt OC, McNeil E, Lufino MM, Seymour L, Channon K, Wade-Martins R. Long-term physiologically regulated expression of the low-density lipoprotein receptor in vivo using genomic DNA mini-gene constructs. Mol Ther 2010;18:317-26.

77 Hibbitt O, Agkatsev S, Owen C, Cioroch M, Seymour L, Channon K, Wade-Martins R. RNAi-mediated knockdown of HMG CoA reductase enhances gene expression from physiologically regulated low-density lipoprotein receptor therapeutic vectors in vivo. Gene Ther 2012;19:463-7.

78 Hobbs HH, Russell DW, Brown MS, Goldstein JL. The LDL receptor locus in familial hypercholesterolemia: mutational analysis of a membrane protein. Annu Rev Genet 1990;24:133-70

79 Cong L, Ran FA, Cox D, Lin S, Barretto R, Habib N, Hsu PD, Wu X, Jiang W, Marraffini LA, Zhang F. Multiplex genome engineering using CRISPR/Cas systems. Science 2013;339:819-23.

80 Chu VT, Weber T, Wefers B, Wurst W, Sander S, Rajewsky K, Kühn R. Increasing the efficiency of homology-directed repair for CRISPR-Cas9-induced precise gene editing in mammalian cells. Nat Biotechnol 2015;33:543-8.

81 Sander JD, Joung JK. CRISPR-Cas systems for editing, regulating and targeting genomes. Nat Biotechnol 2014;32:347-55.

82 Cheng R, Peng J, Yan Y, Cao P, Wang J, Qiu C, Tang L, Liu D, Tang L, Jin J, Huang X, He F, Zhang P. Efficient gene editing in adult mouse livers via adenoviral delivery of CRISPR/Cas9. FEBS Lett 2014;588:3954-8. 